City University of New York (CUNY) CUNY Academic Works

2017

\title{
Joining by Number: Military Intervention in Civil Wars
}

Zachary C. Shirkey

CUNY Hunter College

\section{How does access to this work benefit you? Let us know!}

More information about this work at: https://academicworks.cuny.edu/hc_pubs/280

Discover additional works at: https://academicworks.cuny.edu

This work is made publicly available by the City University of New York (CUNY).

Contact: AcademicWorks@cuny.edu 


\title{
Joining by Number: Military Intervention in Civil Wars
}

\author{
Zachary C. Shirkey \\ Hunter College-CUNY
}

Understanding why and when states militarily intervene in civil wars is crucial. Intervention can increase civil wars' severity and the strategies employed in civil wars are shaped by the possibility of military intervention. This article argues that potential military interveners react to information revealed about warring parties' intentions and relative power. Without revealed information, potential military interveners are unlikely to reconsider their initial decision to remain out of the war. Revealed information causes non-belligerent states to update their expectations about the trajectory of the civil war causing them, at times, to change their calculus about the benefits of belligerency and thus intervene. This helps explain why civil wars spread and when they do so. This explanation is tested using generalized estimating equations on a new dataset of unexpected events for the civil wars in the Correlates of War Intrastate War and PRIO Armed Conflict datasets.

States often worry that civil wars, such as the ongoing Syrian conflict, will draw in outside military forces. ${ }^{1}$ Such concerns about military intervention in civil wars are quite reasonable - three fifths of civil wars experience some level of outside involvement, often by multiple states (Findley and Teo 2006). Previous studies have found that outside involvement can alter the outcome, duration, and severity of civil wars making understanding the dynamics of intervention important for both humanitarian and strategic reasons (Balch-Lindsay and Enterline 2000; Kalyvas and Balcells 2010; Regan 2000; 2002; Regan and Aydin 2006). It may be impossible to fully understand how and why civil wars occur, are fought, and end without understanding why and when military intervention occurs. Yet the timing of military intervention in particular is poorly understood.

\footnotetext{
${ }^{1}$ I would like to thank Henk-Jan Brinkman, John Harden, Michael Lee, Zachary Malitz, Madalene O’Donnell, Gary Uzonyi, and Alex Weisiger for their help. The research was funded in part by PSC-CUNY grants 64029-00 42 and 65525-00 43 .
} 
This article aims to fill that void using insights derived from the bargaining model of war. It argues civil wars are bargaining processes and that events within civil wars, such as battles, reveal information. This information causes outside states to update their expectations about the outcome of the war and the benefits of intervention. In particular, it argues that unexpected events within wars reveal information which causes states to reevaluate the merits of military intervention. The article finds that is indeed the case as military intervention is correlated with and likely caused by unexpected military events and that events of greater magnitude are more strongly correlated with intervention than are lesser events. This is a significant contribution to the literature as it helps explain not only why states intervene, but when they are likely to do so. It differs from prior explanations of intervention as they have tended to focus on which states are likely to join rather than on when intervention is likely to occur. The article also finds that such unexpected events are correlated with and likely causal of states' exits from civil wars and the termination of those wars.

The rest of the article is organized as follows. First, the literature on military intervention in civil wars is reviewed. Next, I construct a new theory of intervention based on revealed information. Then, using a series of generalize estimating equations on a new dataset of unexpected events for civil wars in the Correlates of War (COW) Intrastate War dataset, the article shows that military intervention is correlated with and probably caused by unexpected events. These findings are confirmed by more limited tests on unexpected events data for the civil wars in the PRIO Armed Conflict dataset. Last, the article concludes and considers potential avenues for future research.

\section{The Gap in Our Understanding of Military Intervention}


Prior work has produced several findings in regards to military intervention. First, scholars have found the nearer a state is to a war, the more likely it will intervene as the conflict would be more salient and intervention logistically easier (Aydin 2012; Kathman 2010; Leeds 2005; Regan 2000; Shirkey 2009; 2012; Siverson and Starr 1991; Wallensteen and Sollenberg 1998). Second, great powers are more likely to intervene due to their greater ability to influence the outcome of wars and greater logistical capacity (Altfeld and Bueno de Mesquita 1979; Aydin 2012; Findley and Teo 2006; Shirkey 2009; 2012; Siverson and Starr 1991). Third, allies of belligerents (Findley and Teo 2006; Joyce, Ghosn, and Bayer 2014; Melin and Koch 2010; Shirkey 2009; Siverson and Starr 1991) and fourth, states with cross border ethnic ties (Khosla 1999; Saideman 1997) are more likely to intervene. While important in illuminating which states intervene, by focusing on time invariant structural variables, these findings tell us little about when intervention is likely to occur.

In order to explain the timing of intervention, this article builds on arguments that changes in relative power between belligerents help explain alignment shifts within civil wars in ways that static variables simply cannot (Christia 2012), that wars are bargaining processes, and that wars are mechanisms for revealing information. It argues that shifts in power and changes in intentions, as revealed by events within civil wars, cause states to reconsider their earlier decisions about whether or not to intervene. This in turn often prompts intervention and explains why states would reverse their prior decision to not join the war. States act on this revealed information in response to a variety of motives including perceived opportunities to revise the status quo, the desire to join one side for their own protection, a need to balance, and a desire to affect the outcome of the wars they enter (Altfeld and Bueno de Mesquita 1979; Gent 2008; 
Gleditsch, Salehyan, and Schultz 2008). Thus, revealed information helps explain why civil wars experience military intervention and the timing of that intervention.

This argument is related to, yet distinct from, two other works that have looked at the connection between third parties, belligerents, and events within civil wars. Gleditsch and Beardsley (2004) use event analysis to show that outside third parties are able to bring pressure on belligerent parties and change those parties' behaviors in an attempt to influence the outcome of the conflict. Similarly, Goldstein and Pevehouse (1997) use events data to show that in the Bosnian Civil War outside parties attempting to influence the conflict changed their military and diplomatic tactics in response to battlefield events. This article differs from those studies in that it examines the timing of intervention, focuses narrowly on military intervention, and roots intervention more explicitly within the bargaining model of war.

\section{Revealed Information and Military Intervention}

All wars, including civil wars, are dynamic, evolving processes which clarify the distribution of power, goals, and reservation prices of the belligerents. In other words, wars are a continuation of bargaining in which information is revealed and costs imposed causing the range of acceptable bargains for all parties to shift (Fearon 1995; Goemans 2000; Smith 1998; Wagner 2000). As belligerent powers learn, they continuously weigh the value of proposed offers against the expected value of continued bargaining. Here learning means the updating of expectations in the light of new information or "a change of beliefs (or degree of confidence in one's beliefs) ... as a result of observation and interpretation of experience." (Levy 1994, 283). This learning leads belligerents to alter both their alignments with their fellow belligerents and their demands until an agreement acceptable to all sides is reached (Christia 2012; Cunningham 2010). The lack of such an agreement, tacit or otherwise, is what causes war (Goemans 2000). 
Non-belligerent states view ongoing wars in much the same manner (Balch-Lindsay and Enterline 2000) meaning that civil wars will prompt intervention if an agreement, tacit or otherwise, between a belligerent and a non-belligerent unravels (Cunningham 2010). New information may reveal a need to balance, an opportunity to pick up spoils, or a chance to alter the war's outcome. These dangers and opportunities can be revealed by information about relative strengths, states' intentions, and probable costs. Such information is most likely to be revealed by battles and significant changes in the composition of governments and rebel groups, though other events within civil wars could reveal information as well. While such information would be more difficult for an outsider to obtain than for a belligerent, events in civil wars reveal significant information to non-belligerents through such sources as military observers, intelligence services, journalists, and refugees. Thus, events within civil wars change the range of acceptable settlements for all parties, including for non-belligerent states, and may prompt non-belligerent states to intervene.

For example, take a scenario where C may intervene on A's behalf, in a civil war between $\mathrm{A}$ and $\mathrm{B}$. Events in the civil war can change the probability of $\mathrm{C}$ having military success if it were to join the war on behalf of A and also change the probable settlement of that war. This new probable settlement may be more or less acceptable to $C$ than the previously anticipated settlement. Therefore, events in the ongoing war between A and B should change the range of acceptable settlements between C and B that would keep C out of the war and hence the likelihood that $\mathrm{C}$ will join. See Table I.

[Table 1]

Therefore, military intervention can be thought of as occurring in the following manner. At the beginning of a civil war states decide whether or not to become belligerents. Thereafter 
states become privy to new information revealed by the civil war which alters their beliefs about the probable course of the war, how the war will affect them, and what the effects and costs of intervention would likely be. These new beliefs cause states to update their expected benefits of belligerency relative to peace. As a result, states could be prompted to intervene shortly after information which changes their calculations is revealed.

What sort of events should reveal information to third parties? While some expected events may reveal information, many such events will not as they will be consistent with states' expectations. Unexpected events, however, should be particularly good indicators of when states will join ongoing wars as they cut against prior expectations. For this reason, I use unexpected events as a proxy for revealed information. ${ }^{2}$ An example of an unexpected event would be the advance by rebel groups into southern Mali in 2012. The international community expected that the group, while triumphant in the north, would be checked by the Malian army from advancing south toward the capital of Bamako (Brode 2012). This expectation proved incorrect; thus the initially successful advance into the southern half of the country is an unexpected event-one which in fact triggered French intervention. Similarly, the Saudi intervention into the ongoing Yemeni civil war was triggered by the surprisingly successful advance by Houthi militias into the capital, Sana'a.

H1: Unexpected events should be correlated with and precede military intervention.

Naturally, not all unexpected events are created equal. Some are more important than others. For instance in the American Revolution, the British suffering very high casualties at the Battle of Bunker Hill was unexpected, but still a British victory of sorts. On the other hand, an entire British army surrendering at Saratoga was a major, surprising defeat. Such larger scale

\footnotetext{
${ }^{2}$ Unexpected events are defined in the "Methodology and Results" section.
} 
events will have more influence on the likelihood of intervention as they indicate that the balance of forces and likely settlement are farther from what states expected.

H2: Events of greater magnitude will be more strongly correlated with intervention than events of lesser magnitude.

Additionally, it is possible that political events—-such as protests or changes in the composition of the government—would have a different effect than military events. Both types of events would reveal information about states' intentions, but military events are directly tied to the balance of forces. This difference should result in military events having a greater effect on the likelihood of intervention.

H3: Military events will be more strongly correlated with intervention than political events will be.

Several caveats are in order. First, revealed information is a probabilistic cause, rather than a sufficient cause. Only revealed information that makes joining appear more attractive would increase the probability of intervention. Revealed information which is consistent with non-belligerents' original estimates ${ }^{3}$ or which makes joining the civil war appear less attractive would not increase the likelihood of intervention.

Second, states need to have a great deal at stake in order for new information to trigger belligerency. Even though all states would receive the same new information, they are not all equally likely to join. As discussed above, previous studies of intervention have found that states which are great powers, geographically proximate, or allied to a belligerent are more likely to join. Thus, politically relevant states should be more likely to intervene in response to unexpected events.

Third, if revealed information alters the desirability of belligerency, it follows that such events could cause states to exit as well as join wars (Shirkey 2009). Thus, revealed information

\footnotetext{
${ }^{3}$ Confirming evidence could prompt risk averse states to intervene by increasing the certainty of states' estimates.
} 
should lead to both intervention and war termination. As military intervention obviously cannot occur after a war's termination, revealed information could censor cases and possibly be negatively correlated with military intervention. This seems especially likely to be true after unexpected events of great magnitude as such events would often leave leaders with the choice of seeking peace or risking military collapse.

H4: Unexpected events will be correlated with states exiting wars and with war termination.

Last, some may object to the argument that revealed information can cause wars to spread since private information is a rationalist cause of war (Fearon 1995) and thus conclude revealing information should always lead to peace, not war. This objection is based on the false notion that given war is a mechanism for revealing information, the less private information there is the less likely war is to occur. This can easily be shown to be false. For example, the discovery of Soviet missiles in Cuba in 1962 was a case of private information being revealed, but it increased rather than reduced the likelihood of war as it raised questions about Soviet intentions. Recent formal work has also shown that revealed information can increase the odds of war (Arena and Wolford 2012).

Thus, revealed information helps explain the timing of military intervention in civil wars and provides a motive for that intervention. It does this by revealing potential threats and opportunities to non-belligerent states and changing their beliefs about the merits of belligerency. This argument is tested using generalized estimating equations (GEE) on two new datasets of unexpected events in civil wars in the COW Intrastate War and PRIO Armed Conflict datasets.

\section{Methodology and Results}

While informationalist arguments of intervention in civil wars have been examined using case studies (Shirkey 2012), they have not been subjected to statistical analysis. To remedy this 
the hypotheses advanced above are tested on the 334 civil wars from 1816 to 2008 in the Correlates of War (COW) Intrastate War Dataset version 4.1 (Sarkees and Wayman 2010) and the 235 civil wars from 1946 to 2008 in the PRIO Armed Conflict dataset (Gleditsch et al 2002; Harbom, Melander, and Wallensteen 2008) using GEE models to examine the likelihood of intervention and non-proportional hazard models with a Weibull distribution to examine the likelihood of war termination and state exit. The structure of the data, specifically whether a case represents a non-belligerent war-month, war-month, or belligerent war-month varies by model and will be discussed below as the models are introduced. Prior to justifying the model specifications, the variables will be described.

\section{Description of the Variables}

In Models 1 through 7 the dependent variable is whether a non-belligerent state joined the civil war in a given month after the war's first 30 days as coded by the COW and PRIO datasets. ${ }^{4}$ The 30 day delay is included so as to not conflate the findings with states which joined immediately based on the situation ante bellum rather than due to information revealed by the war. For Models 8 and 10, which examine whether or not unexpected events are correlated with war termination, the dependent variable is whether the civil war ended in a given month. It was taken directly from COW and PRIO. Given that civil wars often recur, the incidence of war termination is greater than the number of wars as civil wars can end more than once. In Model 9, the dependent variable is whether a belligerent state exited the war in a given month as coded in the COW dataset.

Unexpected events are the main independent variable. They are non-trivial events which surprised contemporaries. The unexpected events variable ranges from zero to three. A zero

\footnotetext{
${ }^{4}$ Since multiple states often join the same civil war in the same month, there are more instances of intervention in the non-belligerent war-month dataset than in the war-month dataset.
} 
indicates no unexpected event occurred, while a positive number indicates an unexpected event did occur. The level of the event (one to three) indicates the impact of the event on the military balance of power or the composition and strength of a state's government and polity. Thus, a higher number indicates the event had more of an impact on the course of the war, not that it was more surprising. A Level One event indicates a military performance that was marginally better or worse than expected, surprising important but localized protests and rioting, or deaths of leaders that did not appear likely to alter government policy. Level Two events are major surprising victories or defeats short of a rout, unexpected leadership changes that are likely to significantly alter government policy, and widespread rioting or protests which significantly weaken a government's legitimacy or capabilities. Level Three events are unexpected routs which result in the destruction of large portions of an army or fleet or surprising domestic political events which threaten to topple the government. Such events do not have to knock a state out of the war, but they do have to result in serious damage to one side's capabilities, not just a retreat.

Unexpected events were also categorized as being military or political in nature with military events occurring on the battlefield, while political events occurred away from the battlefield. Both military and political events were recorded for wars in the COW dataset while only military events were recorded for wars in the PRIO dataset. To give an intuitive sense of the variable, examples of events of each type and magnitude which should be familiar to most readers are listed in Table II and a full list of COW events can be found in the supplemental materials online and for PRIO events not already recorded in the COW dataset. For the COW dataset, this coding method resulted in 663 unexpected political events and 578 unexpected 
military events across 334 civil wars. For the PRIO dataset, it results in 797 unexpected military events across 235 wars.

[Table II]

Unexpected events were coded primarily using the Annual Register, a British serial beginning in the late $18^{\text {th }}$ century. The use of a contemporaneous source helped to determine if events were indeed unexpected. An unexpected event was determined to have occurred if the text indicated surprise on the part of third parties or the journalist recording the event who was treated as a proxy for broader opinion. While not a perfect proxy, it was impossible to collect data on the expectations of all non-belligerent states. For civil wars that received scant or no coverage in the Register-mostly $19^{\text {th }}$ century Asian and Latin American civil wars — other sources were used to supplement the Register. This use of supplemental sources helped to ensure that more data was not collected on more prominent civil wars - the very civil wars which might be more likely to experience intervention - than for less prominent wars. Thus, these additional sources helped to avoid introducing bias through the availability of data (see Chojnacki et al 2012). A list of these sources plus a fuller discussion of the coding can be found in the supplemental material online.

In the regressions below, the Any Event variable indicates whether or not an unexpected event of any type occurred in that month or the previous three months. Likewise the Military Event and Political Event variables indicate if an unexpected military or political event occurred in that or the previous three months. The Level One, Two, and Three Event variables indicate if an event of that magnitude occurred. These levels were broken into three dichotomous variables as the effect of moving from one event level to another is unlikely to be equal, and therefore, it is inappropriate to treat it as a continuous or interval variable. The variables are all lagged to allow 
states time to update their expectations and react to the information revealed by the event. ${ }^{5}$ To make sure the results are not sensitive to the length of the lag the regressions were also run using one, two, and four months lags for the events variables in addition to the three month lag reported in the tables. In general, the events variables are robust to the different lags. Instances of the lag chosen mattering are discussed below in the results for the affected model.

There are several control variables. First, the civil war's duration is measured in months up to the current month and was taken directly from COW and PRIO. Second, whether or not a given war-month occurred during the Cold War_coded as between May 1945 and December 1991 inclusive - was included as previous work suggests that proxy wars during that era altered the nature of outside intervention (Tillema 1994). Third, the location of the civil war is captured by a series of dummy variables for Europe, Asia and Oceania, and Africa as the rate of intervention may vary by region (Adebajo 2011). The Western Hemisphere is the residual category. Fourth, the literature suggests that civil wars involving great powers are less likely to attract intervention (Aydin 2012). Therefore, whether or not a great power was involved in the civil war in a given month is recorded. The list of great powers was taken from COW. Fifth, whether an outside state had already intervened was controlled for. This variable is taken directly from COW and PRIO depending on the dataset being used. Finally, Satana (2006) suggests the regime type of the target state matters. Accordingly, whether or not a democracy was involved in the civil war was determined using the Polity IV regime dataset (Marshall and Jaggers 2007) by subtracting the autocracy index from the democracy index. Regimes with a score of six or higher are a coded as a democracy. The descriptive statistics can be seen in Tables IIIa through IIId. ${ }^{6}$ [Tables IIIa, IIIb, IIIc, and IIId]

\footnotetext{
${ }^{5}$ Lags also help avoid serial correlation in the error term (Goldstein and Pevehouse 1997).

${ }^{6}$ The various levels and types of unexpected events do not sum to the total number of unexpected events as lagging these variables creates overlaps in some months.
} 


\section{Methodology}

As the dependent variable is dichotomous, care is required when selecting the appropriate model. Dichotomous dependent variables are best treated using logistic regressions. As the focus of the study is the likelihood of whether intervention will occur in a given month, maximum likelihood estimation (MLE) with a binomial functional form—either logit or probit—would seem the obvious choice.

There are serious problems, however, with MLE models given the nature of the data. States' decisions about intervention are likely neither temporally nor spatially independent of each other. For example, the lack of intervention in January presumably affects the likelihood intervention would occur in February. Additionally, one state entering the civil war affects the probability another will intervene (Leeds 2005). This lack of independence violates a key assumption of MLE models. Normally this could be controlled for by using temporal splines (Beck, Katz, and Tucker 1998). This, however, is impossible as the unexpected events variables are lagged. A random effects logit model is another potential option (Lee and Thompson 2013). The Wooldridge test, however, suggests that autocorrelation in the data cannot be ruled out, thus violating an assumption of logit models (Drukker 2003).

For this reason, GEE models were chosen. GEEs were developed out of generalized linear models and have several advantages. First, they are able to control for temporal dependency and autocorrelation while still incorporating lagged variables (Zorn 2001). ${ }^{7}$ GEEs can also cluster a set of observations thereby partially controlling for spatial dependence. Coefficients in GEE models are interpreted in the same manner as coefficients in any logistic regression. Also, the Huber-White method of calculating robust standard errors can be used in

\footnotetext{
${ }^{7}$ The asymptotic consistency of the $\beta$ s estimated by GEE models holds even if the exact nature of the intra-cluster relationship is unknown. Thus, it is not necessary to know precisely how certain observations are causally linked to control for interdependence.
} 
GEE models. While the errors are asymptotically robust to misspecification in the covariance structure, they are not robust in regards to the conditional mean of $\mathrm{Y}$ given $\mathrm{X}$. Thus, they are only "semi-robust." Therefore a GEE model with a logistic binomial functional form which clusters observations for a given non-belligerent over a particular war (Models 1 and 2) or a simply for a given war (Models 3 through 7) was used. For Models 8 through 10, which examine the effect of unexpected events on war termination and states exiting wars, a non-proportional hazards model with a Weibull distribution was used as several of the control variables violate the proportional hazards assumption. Non-proportional hazard models allow variables to influence both the shape and scale parameters of the regression. Only those variables which influence the shape in a statistically significant way were included in the shape function to avoid obscuring the scale effects for other variables (Cleves et al 2008).

$\underline{\text { Results }}$

In Models 1 and 2 a case represents a war-month for each non-belligerent state. In other words, a case is created for every month that a given state is not in the civil war in question. For example, every month that the United States was a non-belligerent during the Spanish Civil War constitutes a case. If a non-belligerent state joins a civil war it is omitted from the analysis for that civil war for as long as it remains in the war. States in which the civil war occurred are always excluded even if only non-state actors were listed as belligerents in COW. This results over one million cases. When employing a logistic model, including so many cases introduces a bias towards underestimating the likelihood if the dependent variable is a rare event like intervention. To avoid introducing bias it is best practice to sample in part on the dependent variable (King and Zeng 2001) and pare down the data by focusing on politically relevant dyads. Therefore, for Models 1 and 2 only politically relevant non-belligerent states were included- 
great powers, contiguous states, and states which actually intervened. This results in a more manageable number of cases $(87,530)$. This paring down of the data is not repeated in the later models which have far fewer cases. Coefficients and semi-robust standard errors are reported. See Table IV.

[Table IV]

As can be seen in Model 1 of Table IV, both duration and unexpected events are statistically significant. Longer lags do not affect the variables' significance, but for shorter lags the variable is only significant at the 0.10 level. All of the marginal effects are small given the large number of cases. Such low substantive effects are typical of rare events models. Obviously, it is rare for any given state, even a politically relevant one, to intervene in any given month. Still, the occurrence of an unexpected event increases the odds of intervention more than fourfold, from $0.0235 \%$ to $0.099 \%$, holding duration at its mean and the other controls at their median. See Figure 1.

[Figure 1]

As can be seen in Model 2, both military and political events drive the findings for unexpected events in Model 1, though political events are not significantly correlated with late joining if a shorter lag is used (they do remain significant with the longer four month lag). Military events remain significant with both shorter and longer lags. Military events increase likelihood by 3.5 times (from $0.028 \%$ to $0.099 \%$ ) while political events roughly double the likelihood to $0.053 \%$ (see Figure 1). In all models duration is significantly correlated with a reduction in the likelihood of intervention while the Cold War is not statistically significant. Peacekeeping is correlated with further intervention in Models 1 and 2, but not in later models. 
Another way to think about the puzzle of intervention is to think about when a given civil wars experiences outside intervention as opposed to when a given state joins that war. This means the data can be structured as war-months rather than as non-belligerent war-months (Models 3-7). For example, in these models each month of the Spanish Civil War is a single case. This reduces the number of cases allowing all cases to be considered without introducing bias. Again GEE models were used and duration and the Cold War were included as control variables. To these were added the region the civil war was in, whether the civil war had been internationalized, whether a great power was a belligerent, and whether a democracy was a belligerent. The results can be seen in Models 3 through 5 in Table IV. Coefficients and semirobust standard errors are reported.

Once again unexpected events are correlated with intervention (Model 3) and it is military events which drive the results (Model 4). Again holding the other variables at their median or mean the occurrence of an unexpected event increases the odds of joining nearly two and a half times $(0.127 \%$ from $0.052 \%)$. Unexpected events are not significant if a shorter lag is used in Model 3, but they are if a longer lag is used. Military events increase the odds of intervention to $0.152 \%$ from $0.051 \%$, an almost threefold increase (see Figure 2 ). The result is not dependent on the lag chosen. Political events are neither statistically or substantive significant.

[Figure 2]

As can be seen from the $\chi^{2}$, the fit of these models is much better than before despite having far fewer cases. Some of this is due to the new control variables. First, it matters where the civil war occurs. Civil wars in Europe and Africa are significantly more likely to experience intervention than civil wars elsewhere. In Model 3, they increase the odds of joining in any given 
month to $0.201 \%$ and $0.148 \%$ respectively. Model 4 produces similar effects, with Europe and Africa increasing the odds to $0.223 \%$ and $0.145 \%$ respectively. Also, civil wars involving democracies are more likely to have outside states join $(0.129 \%$ in Model 3 and $0.132 \%$ in Model 4), but those involving great powers are less likely to experience intervention with the odds dropping to $0.014 \%$ in both Models 3 and 4 . As before duration is negatively correlated with intervention and the Cold War has no effect. Whether the war was already internationalized through prior interventions and the number of neighboring states also have no effect.

Last, how different magnitude events affect the likelihood of intervention is considered (Model 5). As can be seen, Level Two events are correlated with intervention as expected. They raise the odds of joining from $0.059 \%$ to $0.207 \%$ a three and a half fold increase (see Figure 2). Level One events, however, are not correlated with intervention. This runs against the work's hypothesis to some extent as it is a negative finding for unexpected events, but given that it was also hypothesized that events of a higher magnitude were more likely to cause joining than lesser events, the result is not particularly surprising. What is surprising, however, is that Level Three events are perfectly correlated with non-intervention requiring that they be omitted from the model. ${ }^{8}$ There are several things to take from this. First, such events are very rare. Despite their strong negative correlation with intervention, when aggregated with events of lesser magnitude, unexpected events as a whole are correlated with intervention (Models 1 through 4). Second, recall that unexpected events not only cause non-belligerent states to reconsider their decisions about war and peace, but they also cause belligerent states to do the same. Given that Level Three events are truly massive blows to one side of a civil war, it would not be surprising if such events either knocked belligerents out of the war or caused them to negotiate an end to the conflict. Thus, Level Three events could be censoring the chance for intervention by ending the

\footnotetext{
${ }^{8}$ The results for the control variables remain essentially unchanged.
} 
war. Theoretically, lower level events should also be correlated with the war termination, but not to the level of high magnitude events thus often leaving an opportunity for intervention to occur. As will be seen below in Models 8 through 10 (Tables VI and VII) this is exactly what is happening.

As a robustness check, unexpected military events were coded for the civil wars in the PRIO dataset in case there were concerns that given the different sets of wars in COW and PRIO, the results might not transfer. As can be seen in Models 6 and 7 (Table V) there appears to be little reason to worry. Unexpected military events were significantly correlated with intervention and these results were driven largely by Level Two rather than Level One events. ${ }^{9}$ Once again, Level Three events are perfectly correlated with non-intervention and have to be omitted, but as suggested above and seen below it is because such events drive states to exit wars thereby censoring any chance for intervention. The results for some of the control variables are changed. Prior internationalization of the war is now correlated with further intervention and the Cold War has a significant, negative effect on the likelihood of intervention. This latter result is probably a product of the greater tendency toward intervention in the post-Cold War period while the Cold War period does not look particularly exceptional in comparison to the $19^{\text {th }}$ Century - a period not included in the PRIO dataset. Also in Model 7, the number of neighboring states is positively correlated with intervention.

[Table V]

As mentioned above, unexpected events should cause belligerents to reconsider remaining in the war just as they cause non-belligerents to consider joining. Models 8 through 10 show that this is indeed the case (Tables VI and VII). Control variables are included for the war's

\footnotetext{
${ }^{9}$ Military events are only significant at the 0.10 level with shorter lags in Model 6. The lag chosen does not affect any events variables in Model 7.
} 
region (DeRouen and Sobek 2009; Fearon 2004), whether the conflict had been internationalized (Regan 2002), regime type (Collier, Hoeffler, and Söderbom 2004; DeRouen and Sobek 2009; Fearon 2004), the Cold War (Kalyvas and Balcells 2010), and great power status. These controls are operationalized in the same manner as in previous models. A non-proportional hazards model using a Weibull distribution is used as some of the variables violated the assumption of proportional hazards making Cox models inappropriate. Those variables which violate the proportional hazards assumption are allowed to affect both the scale and the shape of the regression function. Coefficients and robust standard errors are reported.

Models 8 and 10 look at war termination using the COW and PRIO datasets respectively. Each case is a war-month. Model 9 uses the COW dataset and looks at states exiting wars as it is possible for interveners to leave a civil war before that war ends. Therefore, each case in Model 9 represents a belligerent war-month. So for example, every month Italy was involved in the Spanish Civil War would be a case.

For the COW dataset for war termination (Model 8), both Level Two and especially Level Three events increase the odds civil wars will end, though the result for Level Two events is sensitive to the lag specification - it ceases to be significant with either a shorter or longer lag — whereas the result for Level Three events holds using both longer and shorter lags. Importantly, the size of the effect for Level Three events is more than large enough to explain why such events were negatively correlated with intervention in the previous model. Wars experiencing a Level Three event are over six times more likely to terminate within the next four months than if such an event had not occurred. Model 9 looks at if unexpected events increase the odds that states will exit the civil war. Again, Level Three events significant increase the 
odds of exit-in this case over fourfold..$^{10}$ Last, in the PRIO dataset (Model 10), both Level Two and Level Three events significantly increase the odds of war termination. ${ }^{11}$ Level Two events double the likelihood of termination while Level Three events increase the odds of termination by over 66 times. The results from these three models strongly indicate that Level Three events are censoring opportunities for intervention in civil wars by ending those wars. It is this censoring which explains the negative correlation between military intervention and Level Three events in earlier models.

[Tables VI and VII]

\section{Conclusion}

The results show that unexpected events, especially unexpected military events, are significantly correlated with states' decisions to militarily intervene in ongoing civil wars. This is true whether or not the data were structured as non-belligerent war-months for politically relevant states or just as war-months. The results hold for both the COW and PRIO datasets. These results suggest that such events motivate states to intervene in civil wars and help explain when intervention occurs. The analysis also shows that unexpected events were correlated with and likely causal of states exiting civil wars and civil war termination. This is because just like with intervention, such events cause states to reconsider their decisions about belligerency. Taken as a whole, these findings lend support to bargaining explanations of war. Such explanations are compelling only if they can explain initiation, termination, and war expansion for both interstate and civil wars as the logic of bargaining approaches suggests they should apply to all of these areas. Given previous work has found support for bargaining explanations of initiation and termination in both civil and interstate wars as well as intervention in interstate

\footnotetext{
10 The result holds with shorter, but not longer, lags.

11 The results for Level Two variables hold for shorter lags, but hold only at the 0.10 level for longer lags. The results for Level Three variables are not sensitive to the lag chosen.
} 
wars, we can have confidence that the approach is able to explain the full scope and domain of wars.

Thus, the work shows that certain periods in civil wars, specifically those after unexpected events, have an increased rate of military intervention and that unexpected events are more likely to be associated with military intervention than is random noise. This is because these events reveal information about the balance of forces and intentions of the warring parties, thereby potentially destroying tacit agreements to not fight between a warring party and a nonbelligerent state. These results are potentially useful for policy makers concerned with containing civil wars as they suggest when it is most important to undertake robust diplomatic efforts. In particular, diplomatic efforts to prevent military intervention would be most profitable if they focused on civil wars where conditions were rapidly changing. Alas, given that unexpected events by their very nature will come as surprises, preparing ahead of time for such crises would be quite difficult. Thus, while prediction remains elusive, risk management and a concentration of effort is possible.

Clearly more research in this area can be done, perhaps on which sort of unexpected military events are most important, say governmental battlefield defeats, coups, or shifts in territorial control. Likewise, it could be promising to investigate interactions between geography, revealed information, and capabilities. Finally, the directionality of events could be examined. Are states more likely to intervene militarily on behalf of the side that has recently suffered a setback or on the side which is doing unexpectedly well? This relationship might vary—with defeats prompting aid for governments and successes generating aid for rebel groups. Even given these remaining questions, the findings suggest that states need not worry that civil wars where 
little has changed recently are likely to spread if they have not already done so. That is no small thing.

\section{Bibliography}

Adebajo, Adekeye. 2011. UN Peacekeeping in Africa: From the Suez Crisis to the Sudan Conflicts (Boulder: Lynne Rienner).

Altfeld, Michael, and Bruce Bueno De Mesquita. 1979. "Choosing Sides in War," International Studies Quarterly 23:1, 87-112.

Arena, Philip, and Scott Wolford. 2012. "Arms, Intelligence, and War," International Studies Quarterly 56:2, 351-66.

Aydin, Aysegul. 2012. Foreign Powers and Intervention in Armed Conflicts. Stanford: Stanford University Press.

Balch-Lindsay, Dylan, and Andrew Enterline. 2000. "Killing Time: The World Politics of Civil War Duration, 1820-1992,” International Studies Quarterly 44:4, 615-42.

Beck, Nathaniel, Jonathan Katz, and Richard Tucker. 1998. "Taking Time Seriously: TimeSeries - Cross-Section Analysis with a Binary Dependent Variable," American Journal of Political Science 42:4, 1260-88.

Brode, Daniel. 2012. "Rebels on the Rise in Northern Mali," New York Times, April 3.

Chojnacki, Sven, Christian Ickler, Michael Spies, and John Wiesel. 2012. "Event Data on Armed Conflict and Security: New Perspectives, Old Challenges, and Some Solutions," International Interactions 38:4, 382-401.

Christia, Fotini. 2012. Alliance Formation in Civil Wars (Cambridge: Cambridge University Press).

Cleves, Mario A., William W. Gould, Roberto G. Gutierrez, and Yulia Marchenko. 2008. An Introduction to Survival Analysis Using Stata. (College Station: Stata).

Collier, Paul, Anke Hoeffler, and Måns Söderbom. 2004. "On the Duration of Civil War," Journal of Peace Research 41:3, 253-73.

Cunningham, Donald. 2010. "Blocking Resolution: How External States Can Prolong Civil Wars," Journal of Peace Research 47:2, 115-27.

DeRouen, Karl R. Jr., and David Sobek. 2004. "The Dynamics of Civil War Duration and Outcome," Journal of Peace Research 41:3, 303-20. 
Drukker, David. 2003. "Testing for Serial Correlation in Linear Panel-Data Models," Stata Journal 3:2, 168-77.

Fearon, James. 1995. "Rationalist Explanations for War," International Organization 49:3, 379_ 414.

Fearon, James. 2004. "Why Do Some Civil Wars Last So Much Longer than Others?," Journal of Peace Research 41:3, 275-301

Findley, Michael G., and Tze Kwang Teo. 2006. "Rethinking Third Party Interventions into Civil Wars: An Actor-Centric Approach," Journal of Politics 68:4, 828-37.

Gent, Stephen E. 2008. "Going in When It Counts: Military Intervention and the Outcome of Civil Conflicts," International Studies Quarterly 52:4, 713-35.

Gleditsch, Kristian and Kyle Beardsley. 2004. "Nosy Neighbors: Third-Party Actors in Central American Conflicts," Journal of Conflict Resolution 48:3, 379-402.

Gleditsch, Kristian, Idean Salehyan, and Kenneth Schultz. 2008. "Fighting at Home, Fighting Abroad: How Civil Wars Lead to International Disputes," Journal of Conflict Resolution 52:4, 479-506.

Gleditsch, Nils Petter, Peter Wallensteen, Mikael Eriksson, Margareta Sollenberg, and Håvard Strand. 2002. "Armed Conflict 1946-2001: A New Dataset," Journal of Peace Research $39: 5,615-37$.

Goemans, Hein. 2000. War and Punishment: The Causes of War Termination and the First World War (Princeton: Princeton University Press).

Goldstein, Joshua S. and Jon C. Pevehouse. 1997. "Reciprocity, Bullying, and International Cooperation: Time-series Analysis of the Bosnia Conflict," American Political Science Review 91:3, 515-29.

Harbom, Lotta, Erik Melander, and Peter Wallensteen. 2008. "Dyadic Dimensions of Armed Conflict, 1946-2007,” Journal of Peace Research 45:5, 697-710.

Joyce, Kyle A., Faten Ghosn, and Bayer Reşat. 2014. "When and Whom to Join: The Expansion of Ongoing Violent Interstate Conflicts," British Journal of Political Science 44:1, 20538.

Kalyvas, Stathis, and Laia Balcells. 2010. "International System and Technologies of Rebellion: How the End of the Cold War Shaped Internal Conflict," American Political Science Review 104:3, 415-29.

Kathman, Jacob. 2010. "Civil War Contagion and Neighboring Interventions," International Studies Quarterly 54:4, 989-1012. 
Khosla, Deepa. 1999. "Third World States as Intervenors in Ethnic Conflicts: Implications for Regional and International Security," Third World Quarterly 20:6, 1143-56.

King, Gary, and Langche Zeng. 2001. "Logistic Regression in Rare Events Data,” Political Analysis 9:2, 137-63.

Lee, Michael, and William R. Thompson. 2013. “The War Joining Puzzle: Theory, Rivalry Type, and Power Projection," (Indiana University: Manuscript)

Leeds, Brett Ashley. 2005. "Alliances and the Expansion and Escalation of Militarized Interstate Disputes”, in Mintz, A. and Russett, B. (eds.) New Directions for International Relations: Confronting the Method-of-Analysis Problem (New York: Lexington Books).

Levy, Jack S. 1994. "Learning and Foreign Policy: Sweeping a Conceptual Minefield," International Organization 48:2, 279-312.

Marshall, Monty, and Keith Jaggers. 2007. The Polity IV Project: Political Regime Characteristics and Transitions, 1800-2007. (Severn, MD: Center for Systemic Peace).

Melin, Molly M., and Michael T. Koch. 2010. "Jumping into the Fray: Alliances, Power, Institutions, and the Timing of Conflict Expansion," International Interactions 36:1, 127.

Regan, Patrick. 2000. Civil Wars and Foreign Powers: Outside Intervention in Intrastate Conflict (Ann Arbor: University of Michigan Press).

Regan, Patrick. 2002. "Third Party Intervention and the Duration of Interstate Conflicts," Journal of Conflict Resolution 46:1, 55-73.

Regan, Patrick, and Aysegul Aydin. 2006. "Diplomacy and Other Forms of Intervention in Civil Wars," Journal of Conflict Resolution 50:5, 736-56.

Saideman, Stephen. 1997. "Explaining the International Relations of Secessionist Conflicts: Vulnerability vs. Ethnic Ties,” International Organization 51:4, 721-53.

Sarkees, Meredith, and Frank Wayman. 2010. Resort to War: A Data Guide to Inter-State, Extra-State, Intra-State, and Non-State Wars, 1816-2007 (Washington: CQ Press).

Satana, Nil Sedna. 2006. "Third Party Intervention in Civil Conflicts: Sorting Out the Effects of Domestic Factors," (Dissertation: State University of New York at Buffalo).

Shirkey, Zachary. 2009. Is This a Private Fight or Can Anybody Join? The Spread of Interstate War. (Aldershot: Ashgate). 
Shirkey, Zachary. 2012. Joining the Fray: Outside Military Intervention in Civil Wars (Aldershot: Ashgate).

Siverson, Randolph, and Harvey Starr. 1991. The Diffusion of War: A Study of Opportunity and Willingness (Ann Arbor: University of Michigan Press).

Smith, Alastair. 1998. "Fighting Battles, Winning Wars," Journal of Conflict Resolution 42:3, $301-20$.

Tillema, Herbert K. 1994. "Cold War Alliance and Overt Military Intervention, 1945-1991," International Interactions 20:3, 249-78.

Wagner, R. Harrison. 2000. "Bargaining and War," American Journal of Political Science 44:3, $469-84$.

Wallensteen, Peter, and Margareta Sollenberg. 1998. "Armed Conflict and Regional Conflict Complexes, 1989-97," Journal of Peace Research 35:5, 621-34.

Zorn, Christopher. 2001. "Generalized Estimating Equation Models for Correlated Data: A Review with Applications," American Journal of Political Science 45:2, 470-90.

Zachary C. Shirkey (Phd Columbia University 2006) is Associate Professor of Political Science at Hunter College, CUNY. He has published on military intervention, alignment choices, and war duration in the Journal of Peace Research, the International Studies Review, and the Journal of Theoretical Politics. His has written three books: Is This a Private Fight or Can Anybody Join?, Joining the Fray, and Uncertainty, Threat, and International Security. 
Table I: Probable Settlements and State Motives for Joining

\begin{tabular}{|c|c|c|c|}
\hline & $\begin{array}{l}\text { C is Fearful of B's } \\
\text { Victory-Strong to } \\
\text { moderately weak A }\end{array}$ & $\begin{array}{l}\text { C is Fearful of B's } \\
\text { Victory-Very } \\
\text { weak A }\end{array}$ & $\begin{array}{l}\text { C wants to Capitalize } \\
\text { on B's Weakness }\end{array}$ \\
\hline A is Doing Better & $\begin{array}{l}\mathrm{C} \text { is less likely to } \\
\text { join-A is in less need } \\
\text { of aid }\end{array}$ & $\begin{array}{l}\mathrm{C} \text { is more likely to } \\
\text { join-A is now a } \\
\text { more credible } \\
\text { alliance partner }\end{array}$ & $\begin{array}{l}\mathrm{C} \text { is more likely to } \\
\text { join-Can more easily } \\
\text { acquire spoils from } \mathrm{B}\end{array}$ \\
\hline A is Doing Worse & $\begin{array}{l}\mathrm{C} \text { is more likely to } \\
\text { join-Needs to balance } \\
\text { unless B moderates } \\
\text { demands }\end{array}$ & $\begin{array}{l}\mathrm{C} \text { is less likely to } \\
\text { join-A is too weak } \\
\text { to be a credible } \\
\text { alliance partner }\end{array}$ & $\begin{array}{l}\mathrm{C} \text { is less likely to } \\
\text { join-Scared off by } \\
\text { B's success }\end{array}$ \\
\hline
\end{tabular}

Table II: Examples of Each Level of Unexpected Events

\begin{tabular}{|l|l|l|}
\hline & Military Events & Political Events \\
\hline Level 1 & Blackhawk Down Incident—Somalia & Habeas Corpus Suspended-US Civil War \\
\hline Level 2 & Battle of Gettysburg—US Civil War & Emancipation Proclamation—US Civil War \\
\hline Level 3 & FRP Takes Kigali-Second Rwandan & Khomeini returns-Iranian Revolution \\
\hline
\end{tabular}


Table IIIa. Descriptive Statistics for COW Dataset Dummy Variables

\begin{tabular}{|l|r|r|r|r|r|r|}
\hline & \multicolumn{2}{|c|}{$\begin{array}{c}\text { Non-Belligerent } \\
\text { War-Months } \\
\text { Models 1-2 }\end{array}$} & \multicolumn{2}{c|}{$\begin{array}{c}\text { War-Months } \\
\text { Models 3-5 and 8 }\end{array}$} & \multicolumn{2}{c|}{$\begin{array}{c}\text { Belligerent War- } \\
\text { Months Model 9 }\end{array}$} \\
\hline & Zero & One & Zero & One & Zero & One \\
\hline Late Joined & 87,470 & 60 & 9,824 & 50 & ---- & ----- \\
\hline Termination / Exit & ----- & ---- & 9,875 & 333 & 11,967 & 444 \\
\hline Any Event & 55,244 & 32,286 & 6,367 & 3,504 & ---- & ---- \\
\hline Level One Event & ----- & ---- & 6,966 & 2,905 & 8,341 & 4,070 \\
\hline Level Two Event & ----- & ----- & 9,131 & 740 & 11,424 & 987 \\
\hline Level Three Event & ----- & ---- & 9,827 & 44 & 12,357 & 54 \\
\hline Military Event & 70,942 & 16,588 & 8,067 & 1,804 & ----- & ----- \\
\hline Political Event & 68,156 & 19,374 & 7,766 & 2,105 & ---- & ---- \\
\hline Cold War & 50,846 & 36,684 & 5,576 & 4,295 & 6,817 & 5,594 \\
\hline Internationalized & ----- & ---- & 8,326 & 1,545 & 8,408 & 4,003 \\
\hline Great Power in War & ----- & ----- & 8,568 & 1,303 & 10,119 & 2,292 \\
\hline Democracy in War & ----- & ----- & 8,092 & 1,779 & 9,509 & 2,902 \\
\hline Africa & ---- & ---- & 7,451 & 2,420 & 8,572 & 3,839 \\
\hline Europe & ----- & ----- & 8,469 & 1,402 & 10,585 & 1,826 \\
\hline Asia and Oceania & ----- & ---- & 6,454 & 3,417 & 8,636 & 3,775 \\
\hline Peacekeeping & 84,542 & 2,988 & 9,538 & 333 & 11,533 & 878 \\
\hline
\end{tabular}

Table IIIb. Descriptive Statistics for COW Continuous Variables

\begin{tabular}{|l|r|r|r|r|r|r|r|r|r|}
\hline & \multicolumn{2}{|c|}{$\begin{array}{c}\text { Non-Belligerent War- } \\
\text { Months Models 1-2 }\end{array}$} & \multicolumn{3}{c|}{ War-Months } & \multicolumn{3}{c|}{ Belligerent War-Months } \\
& Models 3-5 and 8 & \multicolumn{4}{c|}{ Model 9 } \\
\hline & Mean & Median & St Dev & Mean & Median & St Dev & Mean & Median & St Dev \\
\hline Duration & 43.846 & 25 & 49.805 & 43.143 & 25 & 48.367 & 40.816 & 24 & 44.751 \\
\hline Neighbors & ----- & ----- & ----- & 3.917 & 4 & 2.747 & ---- & ----- & ---- \\
\hline
\end{tabular}


Table IIIc. Descriptive Statistics for PRIO Dataset Dummy Variables

\begin{tabular}{|l|r|r|}
\hline & \multicolumn{2}{|c|}{$\begin{array}{r}\text { War-Months } \\
\text { Models 6-7 and 10 }\end{array}$} \\
\hline & Zero & One \\
\hline Late Joining & 18,376 & 45 \\
\hline War Termination & 18,082 & 339 \\
\hline Military Event & 15,764 & 2,657 \\
\hline Level One Military Event & 16,235 & 2,186 \\
\hline Level Two Military Event & 17,862 & 559 \\
\hline Level Three Military Event & 18,410 & 11 \\
\hline Cold War & 6,948 & 11,473 \\
\hline Internationalized & 16,454 & 1,967 \\
\hline Great Power in War & 16,953 & 1,468 \\
\hline Democracy in War & 11,712 & 6,709 \\
\hline Africa & 13,218 & 5,203 \\
\hline Europe & 17,557 & 864 \\
\hline Asia and Oceania & 7,773 & 10,648 \\
\hline Peacekeeping & 16,750 & 1,671 \\
\hline
\end{tabular}

Table IIIId. Descriptive Statistics for PRIO Continuous Variables

\begin{tabular}{|l|r|r|r|r|r|}
\hline & \multicolumn{5}{|c|}{ War-Months Models 6-7 and 10 } \\
\hline & Mean & Median & St Dev & Min & Max \\
\hline Duration & 102.124 & 61 & 112.757 & 0 & 575 \\
\hline Neighbors & 4.224 & 4 & 2.208 & 0 & 14 \\
\hline
\end{tabular}


Table IV: Intervention and Unexpected Events (COW dataset)

\begin{tabular}{|c|c|c|c|c|c|}
\hline & \multicolumn{2}{|c|}{ Non-Belligerent War-Months } & \multicolumn{3}{|c|}{ War-Months } \\
\hline & $\begin{array}{c}\text { Model 1 } \\
\text { Coefficients } \\
\text { and } \\
\text { Semi-Robust } \\
\text { Standard } \\
\text { Errors }\end{array}$ & $\begin{array}{c}\text { Model 2 } \\
\text { Coefficients } \\
\text { and } \\
\text { Semi-Robust } \\
\text { Standard } \\
\text { Errors }\end{array}$ & $\begin{array}{c}\text { Model 3 } \\
\text { Coefficients } \\
\text { and } \\
\text { Semi-Robust } \\
\text { Standard } \\
\text { Errors }\end{array}$ & \begin{tabular}{|c|} 
Model 4 \\
Coefficients \\
and \\
Semi-Robust \\
Standard \\
Errors
\end{tabular} & $\begin{array}{c}\text { Model 5 } \\
\text { Coefficients } \\
\text { and } \\
\text { Semi-Robust } \\
\text { Standard } \\
\text { Errors }\end{array}$ \\
\hline Any Event & $\begin{array}{l}1.440 * * * \\
(0.292)\end{array}$ & ----- & $\begin{array}{l}0.899 * * \\
(0.305)\end{array}$ & ----- & ----- \\
\hline Military Event & ----- & $\begin{array}{l}1.252 * * * \\
(0.274)\end{array}$ & ----- & $\begin{array}{l}1.093 * * \\
(0.348)\end{array}$ & ---- \\
\hline Political Event & ----- & $\begin{array}{c}0.629^{*} \\
(0.292)\end{array}$ & $\begin{array}{ll}---- \\
\end{array}$ & $\begin{array}{c}0.211 \\
(0.331)\end{array}$ & $\begin{array}{ll}---- \\
\end{array}$ \\
\hline Level One Event & ----- & ----- & ----- & ----- & $\begin{array}{c}0.278 \\
(0.290)\end{array}$ \\
\hline Level Two Event & $\begin{array}{l}---- \\
\end{array}$ & $\begin{array}{l}---- \\
\end{array}$ & $\begin{array}{l}---- \\
\end{array}$ & $\begin{array}{l}---- \\
\end{array}$ & $\begin{array}{l}1.259^{* *} \\
(0.404)\end{array}$ \\
\hline $\begin{array}{l}\text { Level Three } \\
\text { Event }\end{array}$ & ---- & ----- & ----- & ----- & $\begin{array}{l}\text { Omitted due } \\
\text { to collinearity }\end{array}$ \\
\hline Cold War & $\begin{array}{l}-0.495 \\
(0.291)\end{array}$ & $\begin{array}{l}-0.402 \\
(0.311)\end{array}$ & $\begin{array}{c}0.131 \\
(0.319)\end{array}$ & $\begin{array}{c}0.269 \\
(0.349)\end{array}$ & $\begin{array}{c}0.265 \\
(0.327)\end{array}$ \\
\hline Duration & $\begin{array}{l}-0.022 * * * * \\
(0.006) \\
\end{array}$ & $\begin{array}{l}-0.022 * * * \\
(0.006)\end{array}$ & $\begin{array}{l}-0.037 * * \\
(0.013) \\
\end{array}$ & $\begin{array}{l}-0.036^{* *} \\
(0.013) \\
\end{array}$ & $\begin{array}{l}-0.035^{* *} \\
(0.012) \\
\end{array}$ \\
\hline Internationalized & ----- & $\begin{array}{l}---- \\
\end{array}$ & $\begin{array}{c}0.813 \\
(0.418)\end{array}$ & $\begin{array}{c}0.721 \\
(0.431)\end{array}$ & $\begin{array}{c}0.744 \\
(0.421)\end{array}$ \\
\hline $\begin{array}{l}\text { Great Power in } \\
\text { War }\end{array}$ & $\begin{array}{ll}---- \\
\end{array}$ & ----- & $\begin{array}{l}-1.325^{* *} \\
(0.487)\end{array}$ & $\begin{array}{l}-1.292^{* * *} \\
(0.483)\end{array}$ & $\begin{array}{l}-1.261^{*} \\
(0.496)\end{array}$ \\
\hline $\begin{array}{l}\text { Democracy in } \\
\text { War }\end{array}$ & ----- & ----- & $\begin{array}{c}0.914 * \\
(0.380)\end{array}$ & $\begin{array}{c}0.947^{*} \\
(0.374)\end{array}$ & $\begin{array}{l}1.022 * * \\
(0.385)\end{array}$ \\
\hline Africa & ----- & $\begin{array}{l}---- \\
\end{array}$ & $\begin{array}{l}1.054^{* * *} \\
(0.390)\end{array}$ & $\begin{array}{l}1.045^{*} \\
(0.411)\end{array}$ & $\begin{array}{l}1.026^{* *} \\
(0.392)\end{array}$ \\
\hline Europe & ---- & ---- & $\begin{array}{l}1.359^{* * * *} \\
(0.405)\end{array}$ & $\begin{array}{l}1.476^{* * * *} \\
(0.406)\end{array}$ & $\begin{array}{l}1.325^{* * * *} \\
(0.413)\end{array}$ \\
\hline $\begin{array}{l}\text { Asia and } \\
\text { Oceania }\end{array}$ & $\begin{array}{l}---- \\
\end{array}$ & $\begin{array}{ll}---- \\
\end{array}$ & $\begin{array}{c}0.555 \\
(0.486)\end{array}$ & $\begin{array}{c}0.605 \\
(0.493)\end{array}$ & $\begin{array}{c}0.562 \\
(0.486)\end{array}$ \\
\hline Peacekeeping & $\begin{array}{l}1.12^{* * *} \\
(0.387)\end{array}$ & $\begin{array}{l}1.192^{* *} \\
(0.389)\end{array}$ & $\begin{array}{c}0.292 \\
(0.583)\end{array}$ & $\begin{array}{c}0.394 \\
(0.590)\end{array}$ & $\begin{array}{c}0.468 \\
(0.533)\end{array}$ \\
\hline $\begin{array}{l}\text { Neighboring } \\
\text { States }\end{array}$ & ----- & ----- & $\begin{array}{c}0.031 \\
(0.078)\end{array}$ & $\begin{array}{c}0.038 \\
(0.081)\end{array}$ & $\begin{array}{c}0.039 \\
(0.080)\end{array}$ \\
\hline Constant & $\begin{array}{l}-7.370 * * * \\
(0.237)\end{array}$ & $\begin{array}{l}-7.200^{* * * *} \\
(0.212)\end{array}$ & $\begin{array}{l}-6.104^{* * * *} \\
(0.505)\end{array}$ & $\begin{array}{l}-6.164 * * * \\
(0.498)\end{array}$ & $\begin{array}{l}-6.077 * * * \\
(0.480)\end{array}$ \\
\hline Observations & 87,530 & 87,530 & 9,871 & 9,871 & 9827 \\
\hline$\chi^{2}$ & 46.79 & 65.03 & 82.63 & 94.78 & 99.32 \\
\hline
\end{tabular}


Table V: Intervention and Unexpected Military Events (PRIO dataset)

\begin{tabular}{|c|c|c|}
\hline & \multicolumn{2}{|c|}{ War-Months } \\
\hline & $\begin{array}{c}\text { Model 6 } \\
\text { Coefficients } \\
\text { and } \\
\text { Semi-Robust } \\
\text { Standard Errors }\end{array}$ & $\begin{array}{c}\text { Model } 7 \\
\text { Coefficients } \\
\text { and } \\
\text { Semi-Robust } \\
\text { Standard Errors }\end{array}$ \\
\hline Military Event & $\begin{array}{c}0.887 * \\
(0.382)\end{array}$ & ----- \\
\hline $\begin{array}{l}\text { Level One Military } \\
\text { Event }\end{array}$ & ---- & $\begin{array}{c}0.078 \\
(0.371)\end{array}$ \\
\hline $\begin{array}{l}\text { Level Two Military } \\
\text { Event }\end{array}$ & ----- & $\begin{array}{l}1.724 * * * \\
(0.431)\end{array}$ \\
\hline $\begin{array}{l}\text { Level Three Military } \\
\text { Event }\end{array}$ & $\begin{array}{ll}---- \\
\end{array}$ & $\begin{array}{l}\text { Omitted due to } \\
\text { collinearity }\end{array}$ \\
\hline Duration & $\begin{array}{l}-0.006 * * \\
(0.002)\end{array}$ & $\begin{array}{l}-0.005^{* *} \\
(0.002)\end{array}$ \\
\hline Cold War & $\begin{array}{l}-0.867 * \\
(0.378)\end{array}$ & $\begin{array}{l}-0.828 * \\
(0.396)\end{array}$ \\
\hline Internationalized & $\begin{array}{l}1.342 * * * \\
(0.410)\end{array}$ & $\begin{array}{l}1.299 * * \\
(0.426)\end{array}$ \\
\hline Great Power in War & $\begin{array}{c}0.338 \\
(0.585)\end{array}$ & $\begin{array}{c}0.295 \\
(0.604)\end{array}$ \\
\hline Democracy In War & $\begin{array}{c}0.147 \\
(0.342)\end{array}$ & $\begin{array}{c}0.140 \\
(0.336)\end{array}$ \\
\hline Africa & $\begin{array}{l}-0.184 \\
(0.543)\end{array}$ & $\begin{array}{l}-0.228 \\
(0.579)\end{array}$ \\
\hline Europe & $\begin{array}{l}-2.173 \\
(1.390)\end{array}$ & $\begin{array}{l}-2.263 \\
(1.304)\end{array}$ \\
\hline Asia and Oceania & $\begin{array}{l}-0.668 \\
(0.590)\end{array}$ & $\begin{array}{l}-0.650 \\
(0.636)\end{array}$ \\
\hline Peacekeeping & $\begin{array}{l}-0.412 \\
(0.822)\end{array}$ & $\begin{array}{l}-0.282 \\
(0.708)\end{array}$ \\
\hline Neighboring States & $\begin{array}{c}0.146 \\
(0.075)\end{array}$ & $\begin{array}{l}0.152^{*} \\
(0.071)\end{array}$ \\
\hline Constant & $\begin{array}{l}-6.016 * * * \\
(0.658)\end{array}$ & $\begin{array}{l}-6.011 * * * \\
(0.695)\end{array}$ \\
\hline Observations & 18,421 & 18,410 \\
\hline$\chi^{2}$ & 71.39 & 87.00 \\
\hline
\end{tabular}


Table VI: Unexpected Events, War Termination, and State Exit (COW dataset)

\begin{tabular}{|c|c|c|}
\hline & $\begin{array}{c}\text { War } \\
\text { Termination: } \\
\text { War-Months }\end{array}$ & $\begin{array}{c}\text { State Exit: } \\
\text { Belligerent } \\
\text { War-Months }\end{array}$ \\
\hline & $\begin{array}{c}\text { Model 8 } \\
\text { Coefficients } \\
\text { and Robust } \\
\text { Standard Errors }\end{array}$ & $\begin{array}{c}\text { Model 9 } \\
\text { Coefficients } \\
\text { and Robust } \\
\text { Standard Errors }\end{array}$ \\
\hline \multicolumn{3}{|l|}{$\mathbf{t}$ (scale effects) } \\
\hline Level One Event & $\begin{array}{l}-0.145 \\
(0.134)\end{array}$ & $\begin{array}{l}-0.179 \\
(0.114)\end{array}$ \\
\hline Level Two Event & $\begin{array}{c}0.402^{*} \\
(0.172)\end{array}$ & $\begin{array}{c}0.263 \\
(0.156)\end{array}$ \\
\hline Level Three Event & $\begin{array}{l}1.524 * * * \\
(0.354)\end{array}$ & $\begin{array}{l}1.226^{* * * *} \\
(0.381)\end{array}$ \\
\hline Cold War & $\begin{array}{l}-0.468 * * * \\
(0.138)\end{array}$ & $\begin{array}{l}-0.470^{* * * *} \\
(0.121)\end{array}$ \\
\hline Internationalized & $\begin{array}{c}0.043 \\
(0.211)\end{array}$ & $\begin{array}{c}0.187 \\
(0.152)\end{array}$ \\
\hline Great Power in War & $\begin{array}{c}0.016 \\
(0.236)\end{array}$ & $\begin{array}{l}-0.723 \\
(0.466)\end{array}$ \\
\hline Democracy in War & $\begin{array}{l}-0.216 \\
(0.231)\end{array}$ & $\begin{array}{l}-0.228 \\
(0.164)\end{array}$ \\
\hline Africa & $\begin{array}{l}-0.347^{*} \\
(0.158)\end{array}$ & $\begin{array}{l}-0.495^{* * * *} \\
(0.140)\end{array}$ \\
\hline Europe & $\begin{array}{l}-0.254 \\
(0.187)\end{array}$ & $\begin{array}{l}-0.509^{* *} \\
(0.170)\end{array}$ \\
\hline Asia and Oceania & $\begin{array}{l}-0.525^{* *} \\
(0.171)\end{array}$ & $\begin{array}{l}-0.633^{* * * *} \\
(0.152)\end{array}$ \\
\hline Peacekeeping & $\begin{array}{l}-1.163 \\
(0.601)\end{array}$ & $\begin{array}{l}-1.079^{*} \\
(0.511)\end{array}$ \\
\hline Constant & $\begin{array}{l}-2.362^{* * * *} \\
(0.140)\end{array}$ & $\begin{array}{l}-2.354 * * * \\
(0.134)\end{array}$ \\
\hline \multicolumn{3}{|l|}{ ln_p (shape effects) } \\
\hline Peacekeeping & $\begin{array}{l}0.436 * * * \\
(0.115)\end{array}$ & $\begin{array}{l}0.373 * * * \\
(0.101)\end{array}$ \\
\hline Great Power in War & ----- & $\begin{array}{c}0.237^{*} \\
(0.111)\end{array}$ \\
\hline Constant & $\begin{array}{l}-0.170 * * * \\
(0.040)\end{array}$ & $\begin{array}{l}-0.156 * * * \\
(0.037)\end{array}$ \\
\hline Observations & 9,527 & 12,018 \\
\hline$\chi^{2}$ & 63.63 & 72.31 \\
\hline
\end{tabular}


Table VII: Unexpected Events and War Termination (PRIO dataset)

\begin{tabular}{|c|c|}
\hline & $\begin{array}{c}\text { War-Months } \\
\text { Model 10 } \\
\text { Coefficients } \\
\text { and Robust } \\
\text { Standard Errors }\end{array}$ \\
\hline \multicolumn{2}{|l|}{ t (scale effects) } \\
\hline Level One Event & $\begin{array}{l}-0.060 \\
(0.183)\end{array}$ \\
\hline Level Two Event & $\begin{array}{c}0.561 * * \\
(0.216)\end{array}$ \\
\hline Level Three Event & $\begin{array}{l}2.968 * * * \\
(0.535)\end{array}$ \\
\hline Cold War & $\begin{array}{l}-0.123 \\
(0.270)\end{array}$ \\
\hline Internationalized & $\begin{array}{c}0.094 \\
(0.197)\end{array}$ \\
\hline Great Power in War & $\begin{array}{c}0.340 \\
(0.226)\end{array}$ \\
\hline Democracy in War & $\begin{array}{l}-0.416 * \\
(0.168)\end{array}$ \\
\hline Africa & $\begin{array}{l}-1.039 * * \\
(0.355)\end{array}$ \\
\hline Europe & $\begin{array}{l}-0.843 \\
(0.477)\end{array}$ \\
\hline Asia and Oceania & $\begin{array}{l}-1.073 * * * \\
(0.323)\end{array}$ \\
\hline Peacekeeping & $\begin{array}{c}0.102 \\
(0.221)\end{array}$ \\
\hline Constant & $\begin{array}{l}-1.896 * * * \\
(0.324)\end{array}$ \\
\hline \multicolumn{2}{|l|}{ In_p (shape effects) } \\
\hline Cold War & $\begin{array}{l}-0.177 * \\
(0.083)\end{array}$ \\
\hline Africa & $\begin{array}{c}0.252 * \\
(0.109)\end{array}$ \\
\hline Europe & $\begin{array}{l}0.362 * * \\
(0.141)\end{array}$ \\
\hline Asia and Oceania & $\begin{array}{l}0.266^{* *} \\
(0.094)\end{array}$ \\
\hline Constant & $\begin{array}{l}-0.432 * * * \\
(0.096)\end{array}$ \\
\hline Observations & 17,992 \\
\hline$\chi^{2}$ & 65.33 \\
\hline
\end{tabular}


Figure 1: Marginal Effects of Unexpected Events Variables (Models 1-2)
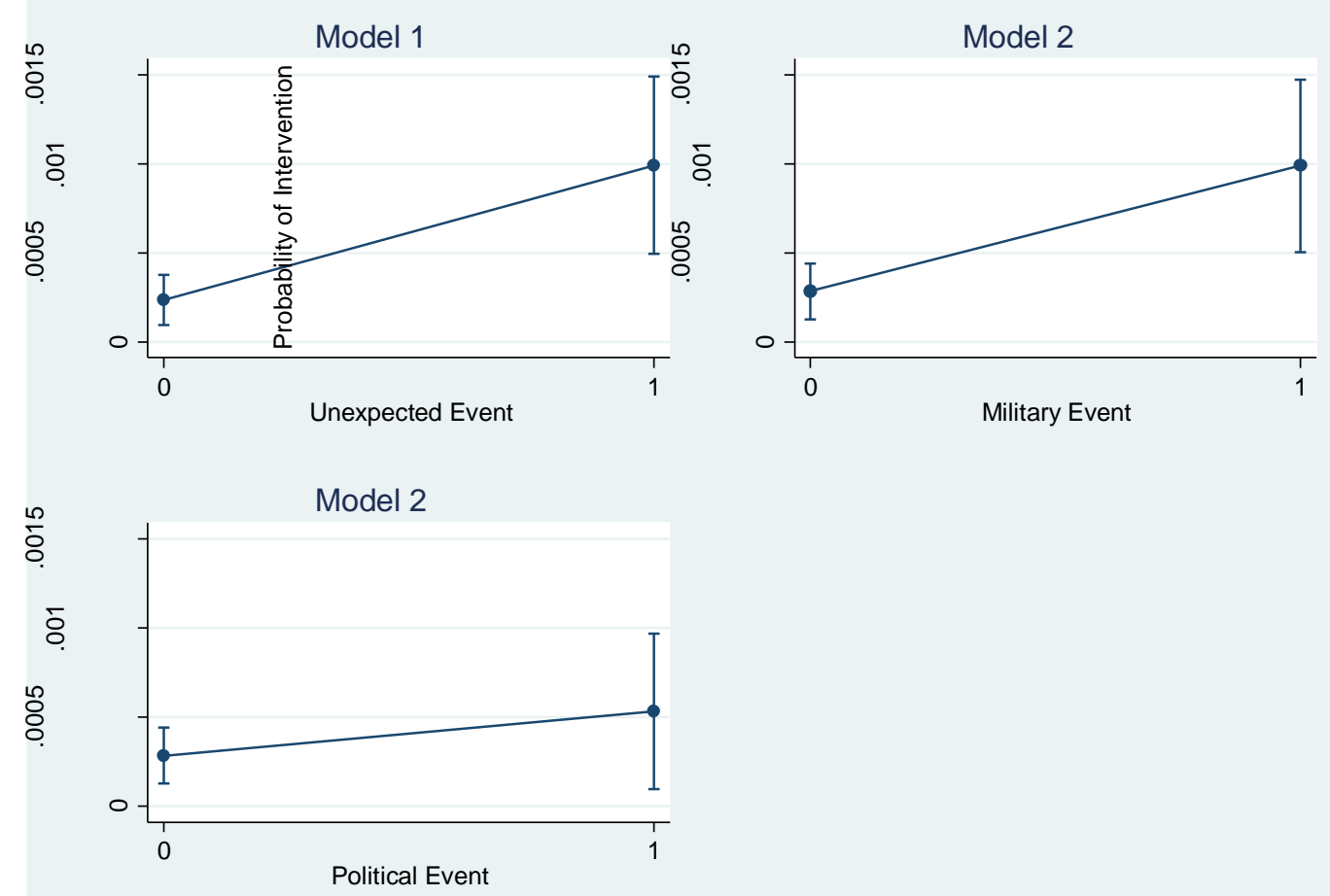

Figure 2: Marginal Effects of Unexpected Events Variables (Models 3-5)
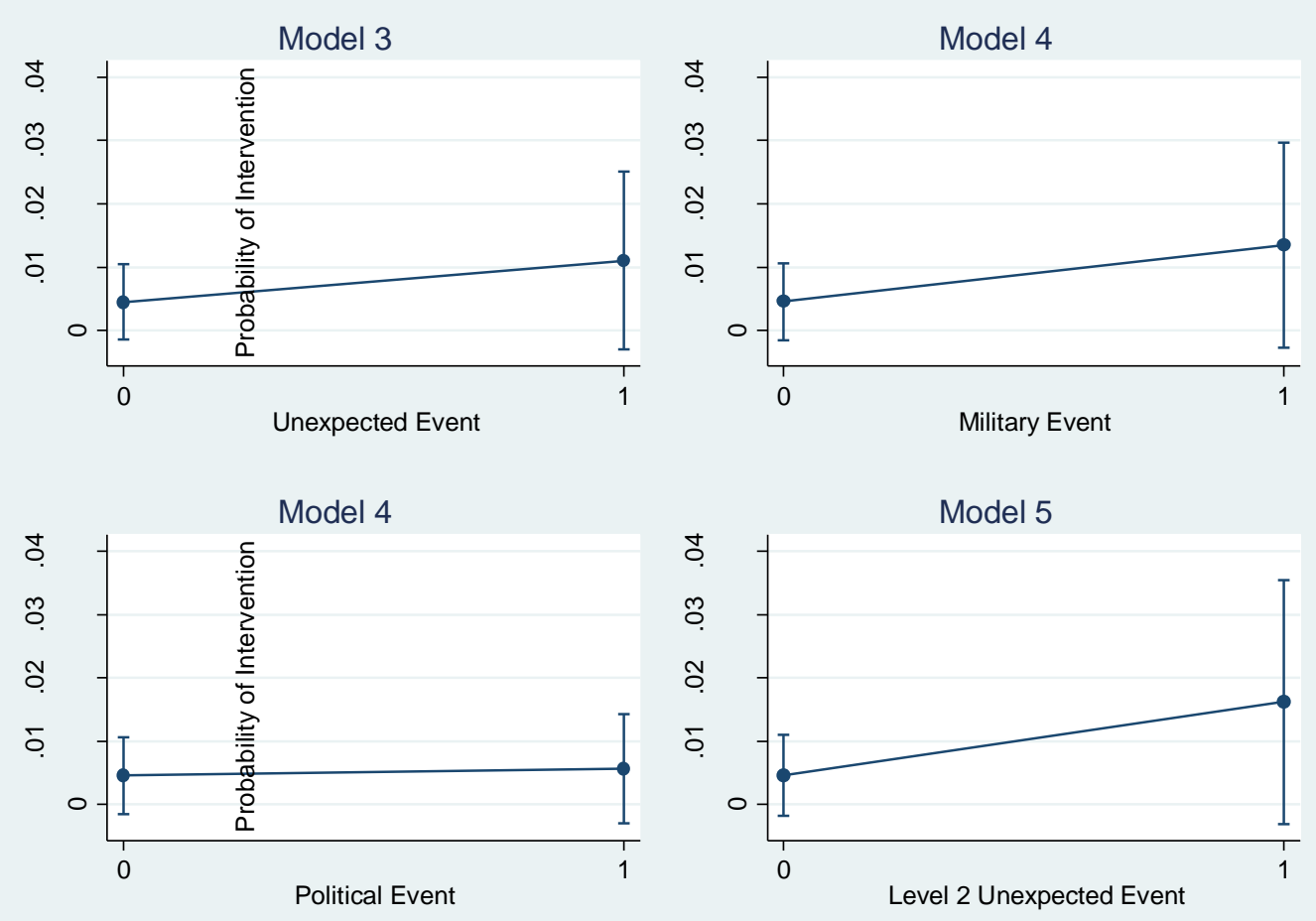